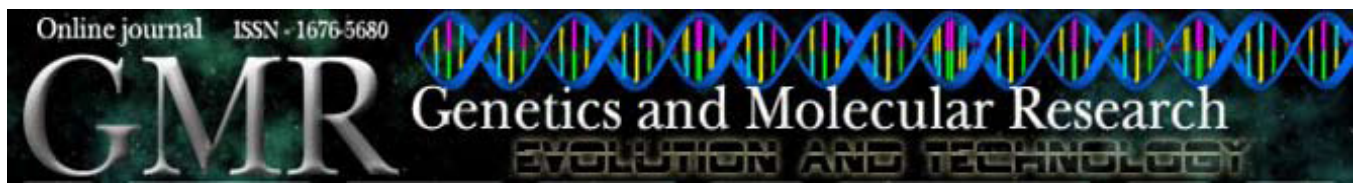

\title{
Diversity of bacterial endophytes in roots of Mexican husk tomato plants (Physalis ixocarpa) and their detection in the rhizosphere
}

H.A. Marquez-Santacruz ${ }^{1}$, R. Hernandez-Leon ${ }^{1}$, M.C. Orozco-Mosqueda ${ }^{2}$, I. Velazquez-Sepulveda ${ }^{1}$ and G. Santoyo ${ }^{1}$

${ }^{1}$ Laboratorio de Recombinacion y Diversidad Genomica, Instituto de Investigaciones Quimico Biologicas,

Universidad Michoacana de San Nicolas de Hidalgo Morelia,

Michoacan, Mexico

${ }^{2}$ Laboratorio de Ecología Microbiana,

Instituto de Investigaciones Quimico Biologicas,

Universidad Michoacana de San Nicolas de Hidalgo Morelia,

Michoacan, Mexico

Corresponding author: G. Santoyo

E-mail: gustavo_santoyo@yahoo.com/gsantoyo@umich.mx

Genet. Mol. Res. 9 (4): 2372-2380 (2010)

Received August 20, 2010

Accepted September 25, 2010

Published December 7, 2010

DOI 10.4238/vol9-4gmr921

\begin{abstract}
Endophytic bacterial diversity was estimated in Mexican husk tomato plant roots by amplified rDNA restriction analysis and sequence homology comparison of the $16 \mathrm{~S}$ rDNA genes. Sixteen operational taxonomic units from the $16 \mathrm{~S}$ rDNA root library were identified based on sequence analysis, including the classes Gammaproteobacteria, Betaproteobacteria, Actinobacteria, and Bacilli. The predominant genera were Stenotrophomonas (21.9\%), Microbacterium (17.1\%), Burkholderia (14.3\%), Bacillus (14.3\%), and Pseudomonas (10.5\%). In a $16 \mathrm{~S}$ rDNA gene library of the same plant species' rhizosphere, only common soil bacteria, including Stenotrophomonas, Burkholderia, Bacillus, and
\end{abstract}


Pseudomonas, were detected. We suggest that the endophytic bacterial diversity within the roots of Mexican husk tomato plants is a subset of the rhizosphere bacterial population, dominated by a few genera.

Key words: Endophytes; Bacterial diversity; Rhizosphere; Mexican husk tomato plants

\section{INTRODUCTION}

The study of plant bacterial endophytes is important for understanding ecological interactions and to develop biotechnological applications (Ryan et al., 2008). Endophytic bacteria can be defined as those bacteria that can colonize the internal tissue of the plant without showing negative signs on their host (Wilson, 1995; Ryan et al., 2008). It has been proposed that rhizospheric bacterial inhabitants can colonize the internal tissues of plants, and therefore many bacterial endophytes appeared to originate from the rhizosphere (Germida et al., 1998). Thus, endophytes have been found in all parts of the plant, including fruits, leaves, stems, seeds, and roots (Sturz et al., 2000; Rosenblueth and MartínezRomero, 2006).

Bacterial endophytes have diverse positive effects on their hosts. Some examples include nitrogen fixation, antibacterial and antifungal activities, as well as plant growth promotion (Brooks et al., 1994; Berg et al., 2005; Tan et al., 2006; Rijavec et al., 2007). Other roles such as synthesis of novel chemicals, resistance to heavy metals and xenobiotic degration have been observed in isolated endophytes (Siciliano et al., 2001; Ryan et al., 2007). Importantly, it has been suggested that investigating the diversity of bacterial endophytes may lead us to identify novel drugs for treatment of diseases in humans, plants and animals (Strobel et al., 2004; Ryan et al., 2008).

In this study, it was estimated bacterial endophytic diversity by amplified rDNA restriction analysis (ARDRA) and sequence comparison of the amplified 16S rDNA genes found in the roots of Mexican husk tomato plants (Physalis ixocarpa Brot.). In pre-Columbian times, the Mexican husk tomato plant was an important staple for the Aztecs and Mayans, and it is endemic of Mexico (Santiaguillo et al., 1994). In addition, it was detected the presence of several endophytic genera in a $16 \mathrm{~S}$ rDNA gene library from the rhizosphere of the same plant roots.

\section{MATERIAL AND METHODS}

\section{Sampling of plants and soil analysis}

Plants of Physalis ixocarpa Brot. and rhizospheric soil were collected in an agricultural field in Salvatierra, Guanajuato, Mexico. Samples were immediately transported to the lab for analysis. The physico-chemical characteristics of the soil were analyzed at the Laboratory of Soil Fertility and Plant Nutrition at INIFAP-Mexico, and were as follows: clay loam texture, $\mathrm{pH} 7.9,2.66 \%$ organic matter, $30.52 \%$ clay, $12.1 \mathrm{~N}$-inorganic (ppm). 


\section{Removal of rhizospheric soil and total DNA extraction}

The samples were collected under sterile conditions. Strongly adhering soil particles were carefully removed from roots and collected in sterile tubes for DNA isolation. Total DNA extraction was done by using the MO-BIO PowerSoil ${ }^{\circledR}$ DNA Isolation Kit, following manufacturer instructions. Extracted DNA solution was completely transparent and was checked by gel electrophoresis and stained with ethidium bromide $(4 \mu \mathrm{g} / \mathrm{mL})$.

\section{Surface sterilization of roots and total DNA extraction}

Once the soil particles attached to the rhizosphere were removed, the roots were washed with distilled sterile water. Roots were immersed in $70 \%$ ethanol for $3 \mathrm{~min}$, washed with fresh sodium hypochlorite solution $\left(2.5 \%\right.$ available $\left.\mathrm{Cl}^{-}\right)$for $5 \mathrm{~min}$, rinsed with $70 \%$ ethanol for $30 \mathrm{~s}$, and finally washed five times with sterile distilled water. To confirm that the sterilization process was successful, the aliquots of the sterile distilled water used in the final rinse were set on TSA, LB and PY medium plates. The plates were examined for bacterial growth after incubation at $28^{\circ} \mathrm{C}$ for 5 days. Roots that were not contaminated as detected by culturedependent sterility test were used for further DNA isolation.

The hot CTAB procedure (Xie et al., 1999) was used with some modifications made by Sun and collaborators (2008). Briefly, about $1 \mathrm{~g}$ of the surface-sterilized rice roots was frozen with liquid nitrogen and ground to a fine powder in a sterilized and precooled mortar. The fine powder was suspended in preheated $9 \mathrm{~mL}$ cetyltrimethylammonium bromide (CTAB) extraction buffer [2\% (w/v) CTAB; $100 \mathrm{mM}$ Tris-HCl, $\mathrm{pH}$ 8.0, $1.4 \mathrm{M} \mathrm{NaCl}, 20 \mathrm{mM}$ EDTA, $1.5 \%$ polyvinyl-pyrrolidone (PVP); $0.5 \% 2$-mercaptoethanol] and mixed by inverting the tube several times, followed by incubation in a $60^{\circ} \mathrm{C}$ water bath for $45-60 \mathrm{~min}$. DNA was then extracted twice with chloroform-isoamylalcohol $(24: 1, \mathrm{v} / \mathrm{v})$, followed by precipitation with 0.6 volumes of isopropanol for $2 \mathrm{~h}$ at $-20^{\circ} \mathrm{C}$. DNA was centrifuged at $12,000 \mathrm{~g}$ for $10 \mathrm{~min}$ at $4^{\circ} \mathrm{C}$, washed with $70 \%$ ethanol, and then air-dried. Finally, the DNA was resuspended in 25 $\mu \mathrm{L}$ sterile distilled water.

\section{Polymerase chain reaction amplification of the bacterial 16S rRNA genes from soil and roots}

Ribosomal 16S rDNA genes were amplified using the universal bacterial primers Fd1, 5'-CAGAGTTTGATCCTGGCTCAG-3' (forward) and Rd1, 5'-AAGGAGGTGATCCAGCC-3' (reverse), corresponding to positions 8 to 28 and 1526 to 1542 from the Escherichia coli 16S rDNA gene, respectively (Weisburg et al., 1991). The following polymerase chain reaction (PCR) conditions were used: an initial denaturation at $95^{\circ} \mathrm{C}$ for $3 \mathrm{~min} ; 30$ cycles of $1 \mathrm{~min}$ at $95^{\circ} \mathrm{C}$ for denaturation, $1 \mathrm{~min}$ at $53^{\circ} \mathrm{C}$ for annealing, and $2 \mathrm{~min}$ at $72^{\circ} \mathrm{C}$ for extension, and a final extension step at $72^{\circ} \mathrm{C}$ for $5 \mathrm{~min}$. The same universal bacterial primers were used for amplification of the bacterial 16S rRNA genes from separate soil and husk tomato root DNA templates.

Polymerase chain reaction amplifications were performed with a TC-412 Techne Thermal Cycler. GoTaq ${ }^{\circledR}$ Master Mixes tubes (Promega) were used (tubes are supplied with enzyme, magnesium, dNTPs, and buffer). Only $0.1 \mu \mathrm{g}$ template DNA and 50 pmol of each primer were added to each tube. 


\section{S rDNA gene cloning, screening by ARDRA and sequencing}

PCR products corresponding to the $16 \mathrm{~S}$ rDNA genes were excised from $1 \%$ agarose gels and purified using the Wizard ${ }^{\circledR}$ SV Gel and PCR Clean-Up System (Promega) according to manufacturer instructions. The purified PCR fragments were then cloned into the pGEMT Easy Vector (Promega) and the resulting ligation products were used to transform competent $E$. coli cells. Positive white clones were detected on LB medium containing $80 \mu \mathrm{g} /$ $\mathrm{mL} \mathrm{X-Gal} \mathrm{and} 0.5 \mathrm{mM}$ IPTG. Restriction analysis of recombinant plasmids was done with EcoRI nuclease to detect the inserts. The 16 rDNA genes were additionally PCR amplified with vector primers (M13 forward and reverse) from positive clones and then purified and analyzed by digestion with $R s a \mathrm{I}$ and HaeIII. The restriction fragments were separated on a $2.5 \%$ agarose gel running in $1 \mathrm{X}$ TAE buffer at $90 \mathrm{~V}$ for approximately $1 \mathrm{~h}$. Fragments shorter than $90 \mathrm{bp}$ were not taken into consideration. According to ARDRA patterns, clones were grouped into operational taxonomic units (OTUs). Representative OTUs from husk tomato roots were chosen to be commercially sequenced. Highly similar ARDRA patterns from the rhizospheric soil 16S rDNA genes with the 16S rDNA sequences from roots were also chosen to be sequenced.

\section{Sequence analysis of $16 \mathrm{~S}$ rDNA genes}

The possibility to obtain chimeric sequences was analyzed by using the CHIMERA CHECK program of the Ribosomal Database Project (Maidak et al., 1999). Sequences considered to be chimeras were discarded, as well as those with no homology to ribosomal genes. All sequences obtained were compared with sequences in the GenBank (NCBI) database by using the BLASTN program, to obtain the best matching sequences.

\section{Nucleotide sequence accession numbers}

The nucleotide sequence data reported here were deposited in the GenBank under the accession numbers HM216894-HM216910.

\section{RESULTS}

\section{ARDRA and clone library analysis in roots and rhizosphere}

The 16S rDNA genes were amplified by PCR from the roots of Mexican husk tomato plants and a clone library was constructed. One hundred and forty-six clones were identified with the correct insert and screened by ARDRA. According to ARDRA restriction patterns, 23 OTUs were identified. Two representative clones from each OTU were randomly selected for $16 \mathrm{~S}$ sequence analysis. Three clone sequences did not show similarity with bacterial $16 \mathrm{~S}$ sequences and were discarded. Another 4 clones, although suggesting a different ARDRA banding pattern, with the sequence homology analysis, were found to be $100 \%$ identical to other $16 \mathrm{~S}$ inserts. At the end, the clone library contained 16 different OTUs (Table 1). 
Table 1. Diversity of endophytic bacteria in the roots of Mexican husk tomato plants.

\begin{tabular}{lclr}
\hline Class & No. of OTUs & NCBI closest match & Identity \\
\hline Gram-negative & & & $100 \%$ \\
Gammaproteobacteria & 7 & Pantoea sp & $100 \%$ \\
& & Pseudomonas stutzeri & $100 \%$ \\
& Pseudomonas syringae pv tomato & $100 \%$ \\
& Pseudomonas syringae pv tabaci & $100 \%$ \\
& & Stenotrophomonas maltophilia & $100 \%$ \\
Betaproteobacteria & Stenotrophomonas sp & $99 \%$ \\
Uncultured & Xanthomonas campestris & $100 \%$ \\
Gram-positive & 1 & Burkholderia cepacia & $100 \%$ \\
Actinobacteria & 1 & Uncultured bacterium & $100 \%$ \\
& 4 & Microbacterium sp & $100 \%$ \\
& & Microbacterium foliorum & $98 \%$ \\
Bacilli & & Cellulomonas sp & $99 \%$ \\
& & Cellulomonas xylanilitica & $100 \%$ \\
Uncultured & 2 & Bacillus subtilis & $100 \%$ \\
\hline
\end{tabular}

OTUS = operational taxonomic units.

In order to identify potential endophytic bacteria in the rhizosphere, a clone library from the rhizosphere of husk tomato plants was constructed. One hundred and twenty-two clones were screened by ARDRA. Four ARDRA restriction patterns showed an identical banding pattern with those of the endophytic clone library. Three representative clones were selected for sequencing and four OTUs were identified.

\section{Comparison of ARDRA banding patterns found in roots and rhizosphere clone libraries}

Figure 1 shows the number of OTUs detected by ARDRA banding pattern in the $16 \mathrm{~S}$ rDNA clone libraries of Mexican husk tomato plant roots and rhizosphere. The rhizosphere clone library consisted of 86 ARDRA banding patterns of 122 clones analyzed, versus the 16 ARDRA banding patterns of 146 total clones analyzed in the clone library of roots. As expected, this result suggests a higher bacterial diversity in the rhizosphere compared to that in the plant roots.

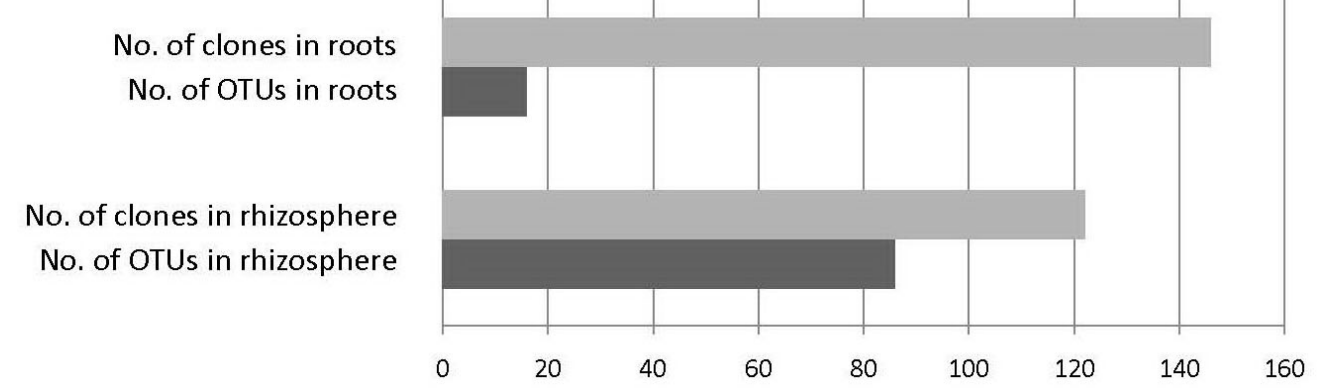

Figure 1. Number of operational taxonomic units (OTUs) and clones analyzed in roots and rhizosphere libraries. See text for details. 


\section{Blast analysis of 16S rDNA genes from the endophytic bacterial community of roots and rhizosphere}

The blast search analysis suggests that our library from Mexican husk tomato roots contained 16 OTUs, including classes of Gammaproteobacteria, Betaproteobacteria, Actinobacteria, Bacilli, and uncultured bacteria. The predominant genus in the 16S rDNA gene library was Stenotrophomonas with $21.9 \%$ of the total clone library, as well as Microbacterium (17.1\%), Burkholderia (14.3\%), Bacillus (14.3\%), and Pseudomonas (10.5\%). Other $16 \mathrm{~S}$ sequences showed identity with the genera Pantoea, Xanthomonas, Cellulomonas, uncultured Gram-negative, and uncultured Bacillus (Figure 2).

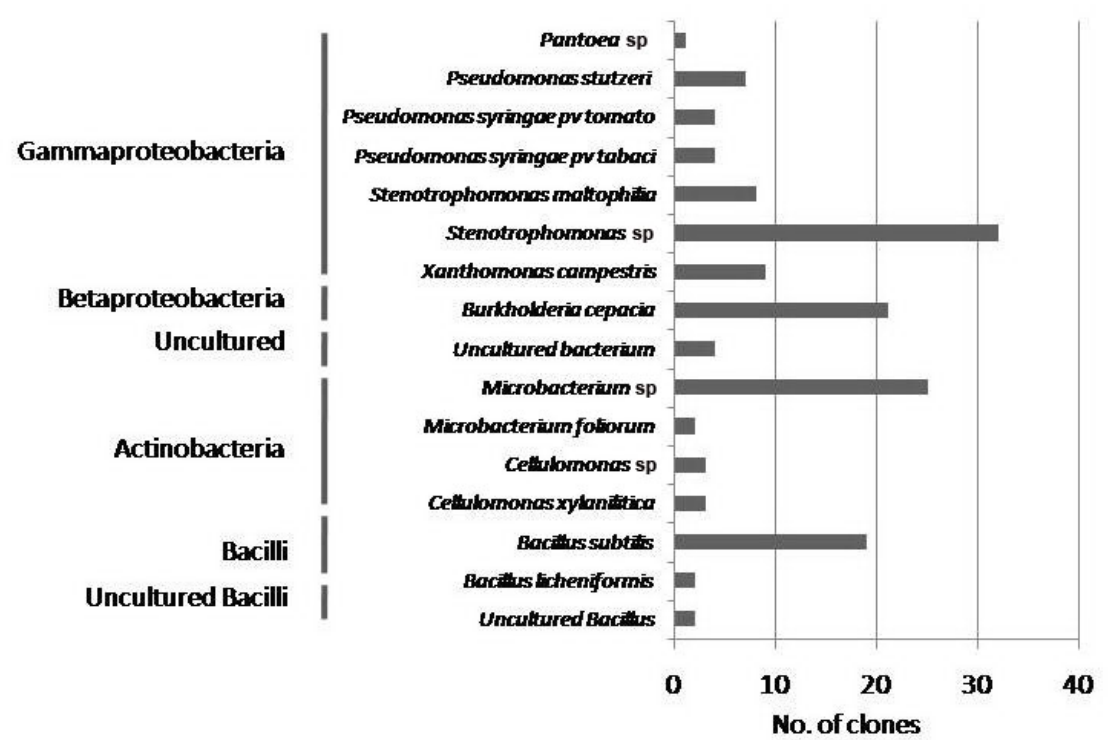

Figure 2. Number of clones detected in the root clone library according to their closest NCBI best match. See text for details.

In the 16S rDNA gene library of the Mexican husk tomato rhizosphere, only the common soil bacteria, including Stenotrophomonas, Burkholderia, Bacillus, and Pseudomonas, were detected. According to the ARDRA pattern, the genus Pseudomonas represented 26.84\% (22 clones) of the total clone library, and the genus Bacillus with $14.64 \%$ (12 clones), as well as Stenotrophomonas and Burkholderia with 9.76\% (8 clones each).

\section{DISCUSSION}

Endophytic bacteria have been found in almost every plant studied (Ryan et al., 2008). There are many examples of reported bacterial endophytes and plants harboring them, including rice, banana, wheat, sugarcane, carrot, maize, soybean, potato, citrus plants, among others (Sturz et al., 2000; Rosenblueth and Martínez-Romero, 2006). Here, we have reported the endophytic bacterial diversity in the roots of Mexican husk tomato plants. 
Molecular approaches based on ARDRA and 16S rDNA gene sequencing analysis, with all their limitations, are an excellent way to study the cultivable and non-cultivable bacterial diversity of plant endophytes. In this study, we analyzed the endophytic bacterial diversity of husk tomato roots. Our results suggest that the most dominant group was affiliated with Gammaproteobacteria, which is consistent with other studies (Chelius and Triplett, 2001; Kaiser et al., 2001; Sun et al., 2008). This class included 7 of 16 OTUs found in the library, which means more than 50\%. Forty-one clones showed high identity with the Stenotrophomonas sp and S. malthophilia species. Stenotrophomonas species have been isolated or detected as endophytes from rice roots (Sun et al., 2008), dune grasses (Dalton et al., 2004) and cotton roots and stems (McInroy and Kloepper, 1995). Some studies have reported species of Stenotrophomonas as a plant growth-promoting bacterium that can suppress disease development by secretion of some compounds, such as the antibiotic maltophilin (Jakobi et al., 1996). The second most dominant group was Microbacterium sp, which has been reported in endophytic association with different plants and maize kernels (Zinniel et al., 2002; Conn and Franco, 2004; Rijavec et al., 2007). In fact, Conn and Franco (2004) reported several Microbacterium species in an analysis of the endophytic populations in the roots of wheat (Triticum aestivum L.), being the predominant genus.

Other 16S rDNA sequences in our clone library showed high identity with Pseudomonas, Burkholderia and Bacillus. Such genera have been widely studied for their diverse range of secondary metabolic products including antibiotics, volatile organic compounds, antifungal, antiviral, and insecticidal agents, and other compounds (Lodewyckx et al., 2001; Ryan et al., 2008).

The presence of nine clones, which had identity with the phytopathogen Xanthomonas campestris, was also detected in our clone library. X. campestris is a well-known pathogen of diverse plants (Bashan et al., 1982; Guevara and Maselli, 2005). Bashan et al. (1982) reported the survival of $X$. campestris pv. vesicatoria living endophytically in peeper seeds and roots without showing scab symptoms, although the appearance of the disease in some growing seasons was not discarded. In our study, no disease symptoms in the husk tomato plants were observed at the time of the collection. According to diverse studies, endophytic populations can be affected by biological or environmental factors, such as plant age, tissue type and time of sampling (Siciliano et al., 1998; Araujo et al., 2001; Adams and Kloepper, 2002). The analysis of pathogenic activities in isolates of endophytic $X$. campestris strains could be an interesting subject to research.

Pantoea and Cellulomonas are another two genera, found in our clone library, that are endophytes of the Mexican husk tomato plants. Pantoea is an endophytic resident of different plants, such as rice, soybean, sweet potato, grapevine, and maize (Elvira-Recuenco and van Vuurde, 2000; Bulgari et al., 2009). Interestingly, the strain TR-5 of Pantoea ananatis isolated from maize kernels inhibited in vitro the growth of the fungus Lecanicillium aphanocladii. Zinniel et al. (2002) isolated species of Cellulomonas from plant tissues and showed good ability to colonize and persist. Thus, these endophytes could be isolated from husk tomato plants, which may be useful for biocontrol or other applications.

According to Germida et al. (1998) the endophyte population can be considered as a subset of the rhizosphere population. In this study, this was confirmed by constructing a $16 \mathrm{~S}$ rDNA clone library from the rhizosphere of Mexican husk tomato plants, where only the predominant soil bacteria, including Stenotrophomonas, Burkholderia, Bacillus, and Pseudomonas were detected by ARDRA banding profile and 16S rDNA sequencing. 
Another predominant root endophyte genus was Microbacterium; however, it was not detected by ARDRA profile in the rhizosphere clone library. A complete sequencing analysis of the rhizosphere clone library could deny or confirm this. The ARDRA banding profile of the rhizosphere was more complex and diverse than that of the plant roots (Figure 1). This is consistent with the work by Germida et al. (1998) who analyzed the diversity of bacteria in the rhizosphere and roots of wheat and canola. They found a less diverse endophytic population than the rhizosphere, and apparently the endophytes appeared to originate from the rhizosphere. In this manner, rhizospheric bacteria can also be a source for isolating endophytic bacteria with potential for use in different biotechnological applications.

\section{ACKNOWLEDGMENTS}

Research in our laboratory was partially supported by Coordinación de la Investigacion Cientifica de la Universidad Michoacana de San Nicolas de Hidalgo and Programa de Mejoramiento del Profesorado-Secretaria de Educacion Publica, Mexico.

\section{REFERENCES}

Adams PD and Kloepper JW (2002). Effect of host genotype on indigenous bacterial endophytes of cotton (Gossypium hirsutum L.). Plant Soil 240: 181-189.

Araujo WL, Maccheroni W Jr, Aguilar-Vildoso CI, Barroso PA, et al. (2001). Variability and interactions between endophytic bacteria and fungi isolated from leaf tissues of citrus rootstocks. Can. J. Microbiol. 47: 229-236.

Bashan Y, Diab S and Okon Y (1982). Survival of Xanthomonas campestris pv. vesicatoria in pepper seeds and roots in symptomless and dry leaves in non-host plants and in the soil. Plant Soil 68: 161-170.

Berg G, Krechel A, Ditz M, Sikora RA, et al. (2005). Endophytic and ectophytic potato-associated bacterial communities differ in structure and antagonistic function against plant pathogenic fungi. FEMS Microbiol. Ecol. 51: 215-229.

Brooks DS, Gonzalez CF, Appel DN and Filer TH (1994). Evaluation of endophytic bacteria as potential biological control agents for oak wilt. Biol. Control. 4: 381.

Bulgari D, Casati P, Brusetti L, Quaglino F, et al. (2009). Endophytic bacterial diversity in grapevine (Vitis vinifera L.) leaves described by 16S rRNA gene sequence analysis and length heterogeneity-PCR. J. Microbiol. 47: 393-401.

Chelius MK and Triplett EW (2001). The diversity of archaea and bacteria in association with the roots of Zea mays L. Microb. Ecol. 41: 252-263.

Conn VM and Franco CM (2004). Analysis of the endophytic actinobacterial population in the roots of wheat (Triticum aestivum L.) by terminal restriction fragment length polymorphism and sequencing of 16S rRNA clones. Appl. Environ. Microbiol. 70: 1787-1794.

Dalton DA, Kramer S, Azios N, Fusaro S, et al. (2004). Endophytic nitrogen fixation in dune grasses (Ammophila arenaria and Elymus mollis) from Oregon. FEMS Microbiol. Ecol. 49: 469-479.

Elvira-Recuenco M and van Vuurde JW (2000). Natural incidence of endophytic bacteria in pea cultivars under field conditions. Can. J. Microbiol. 46: 1036-1041.

Germida JJ, Siciliano SD, Freitas JR and Seib AM (1998). Diversity of root-associated bacteria associated with fieldgrown canola (Brassica napus L.) and wheat (Triticum aestivum L.). FEMS Microbiol. Ecol. 26: 43-50.

Guevara Y and Maselli A (2005). Bacteriosis en cilantro (Coriandrum sativum L.) causada por Xanthomonas campestris (Pammel) Dowson en Venezuela. Rev. Mex. Fitopatol. 23: 97-100.

Jakobi M, Winkelmann G, Kaiser D, Kempler C, et al. (1996). Maltophilin: a new antifungal compound produced by Stenotrophomonas maltophilia R3089. J. Antibiot. 49: 1101-1104.

Kaiser O, Puhler A and Selbitschka W (2001). Phylogenetic analysis of microbial diversity in the rhizoplane of oilseed Rape (Brassica napus cv. Westar) employing cultivation-dependent and cultivation-independent approaches. Microb. Ecol. 42: 136-149.

Lodewyckx C, Taghavi S, Mergeay M, Vangronsveld J, et al. (2001). The effect of recombinant heavy metal-resistant endophytic bacteria in heavy metal uptake by their host plant. Int. J. Phytoremed. 3: 173-187.

Maidak BL, Cole JR, Parker CT Jr, Garrity GM, et al. (1999). A new version of the RDP (Ribosomal Database Project). Nucleic Acids Res. 27: 171-173. 
McInroy JA and Kloepper JW (1995). Survey of indigenous bacterial endophytes from cotton and sweet corn. Plant Soil 173: $337-342$.

Rijavec T, Lapanje A, Dermastia M and Rupnik M (2007). Isolation of bacterial endophytes from germinated maize kernels. Can. J. Microbiol. 53: 802-808.

Rosenblueth M and Martínez-Romero E (2006). Bacterial endophytes and their interactions with hosts. Mol. Plant Microbe Interact. 19: 827-837.

Ryan RP, Ryan DJ, Sun YC, Li FM, et al. (2007). An acquired efflux system is responsible for copper resistance in Xanthomonas strain IG-8 isolated from China. FEMS Microbiol. Lett. 268: 40-46.

Ryan RP, Germaine K, Franks A, Ryan DJ, et al. (2008). Bacterial endophytes: recent developments and applications. FEMS Microbiol. Lett. 278: 1-9.

Santiaguillo HJF, López RM, Peña LA, Cuevas SJA, et al. (1994). Distribución, colecta y conservación de germoplasma de tomate de cáscara (Physalis ixocarpa Brot.). Rev. Chap. Ser. Hort. 2: 125-129.

Siciliano SD, Theoret CM, de Freitas JR, Huci PJ, et al. (1998). Differences in the microbial communities associated with the roots of different cultivars of canola and wheat. Can. J. Microbiol. 44: 844-851.

Siciliano SD, Fortin N, Mihoc A, Wisse G, et al. (2001). Selection of specific endophytic bacterial genotypes by plants in response to soil contamination. Appl. Environ. Microbiol. 67: 2469-2475.

Strobel G, Daisy B, Castillo U and Harper J (2004). Natural products from endophytic microorganisms. J. Nat. Prod. 67: 257-268.

Sturz AV, Christie BR and Nowak J (2000). Bacterial endophytes: Potential role in developing sustainable systems of crop production. Crit. Rev. Plant. Sci. 19: 1-30.

Sun L, Qiu F, Zhang X, Dai X, et al. (2008). Endophytic bacterial diversity in rice (Oryza sativa L.) roots estimated by $16 \mathrm{~S}$ rDNA sequence analysis. Microb. Ecol. 55: 415-424.

Tan HM, Cao LX, He ZF, Su GJ, et al. (2006). Isolation of endophytic actinomycetes from different cultivars of tomato and their activities against Ralstonia solanacearum in vitro. World J. Microbiol. Biotechnol. 22: 1275-1280.

Weisburg WG, Barns SM, Pelletier DA and Lane DJ (1991). 16S ribosomal DNA amplification for phylogenetic study. J. Bacteriol. 173: 697-703.

Wilson D (1995). Endophyte: the evolution of a term, and clarification of its use and definition. Oikos 73: 274-276.

Xie Zh-W, Ge S and Hong D-Y (1999). Preparation of DNA from silica gel dried mini-amount of leaves of Oryza rufipogon for RAPD study and total DNA bank construction. Acta Bot. Sin. 41: 802-807.

Zinniel DK, Lambrecht P, Harris NB, Feng Z, et al. (2002). Isolation and characterization of endophytic colonizing bacteria from agronomic crops and prairie plants. Appl. Environ. Microbiol. 68: 2198-2208. 